\title{
Correction to: Conserved
} and non-conserved functions of the rice homologs of the Arabidopsis trichome initiation-regulating MBW complex proteins

Kaijie Zheng ${ }^{1,2+}$, Xutong Wang ${ }^{2 \dagger}$, Yating Wang ${ }^{2}$ and Shucai Wang ${ }^{2,3^{*}}$

\section{Correction to: BMC Plant Biol 21, 234 (2021)}

https://doi.org/10.1186/s12870-021-03035-0

Following publication of the original article [1], Authors found a minor error in the equal contributors' statement. "Kaijie Zheng and Xutong Wang contributed equally to this work" was missing.

The original article has been corrected.

\begin{abstract}
Author details
'Key Laboratory of Soybean Molecular Design Breeding, Northeast Institute of Geography and Agroecology, Chinese Academy of Sciences, Changchun, China. ${ }^{2}$ Key Laboratory of Molecular Epigenetics of MOE, Institute of Genetics and Cytology, Northeast Normal University, Changchun, China. ${ }^{3}$ Laboratory of Plant Molecular Genetics \& Crop Gene Editing, School of Life Sciences, Linyi University, Linyi, China.
\end{abstract}

Published online: 17 June 2021

\section{Reference}

1. Zheng $K$, Wang $X$, Wang $Y$, et al. Conserved and non-conserved functions of the rice homologs of the Arabidopsis trichome initiation-regulating MBW complex proteins. BMC Plant Biol. 2021;21:234. https://doi.org/10. 1186/s12870-021-03035-0.

The original article can be found online at https://doi.org/10.1186/s12870021-03035-0.

\footnotetext{
*Correspondence: wangshucai@yahoo.com

${ }^{\dagger}$ Kaijie Zheng and Xutong Wang contributed equally to this work.

${ }^{3}$ Laboratory of Plant Molecular Genetics \& Crop Gene Editing, School

of Life Sciences, Linyi University, Linyi, China

Full list of author information is available at the end of the article
}

(C) The Author(s) 2021. Open Access This article is licensed under a Creative Commons Attribution 4.0 International License, which permits use, sharing, adaptation, distribution and reproduction in any medium or format, as long as you give appropriate credit to the original author(s) and the source, provide a link to the Creative Commons licence, and indicate if changes were made. The images or other third party material in this article are included in the article's Creative Commons licence, unless indicated otherwise in a credit line to the material. If material is not included in the article's Creative Commons licence and your intended use is not permitted by statutory regulation or exceeds the permitted use, you will need to obtain permission directly from the copyright holder. To view a copy of this licence, visit http://creativecommons.org/licenses/by/4.0/. The Creative Commons Public Domain Dedication waiver (http://creativeco mmons.org/publicdomain/zero/1.0/) applies to the data made available in this article, unless otherwise stated in a credit line to the data. 